\title{
Developing A Lesson Study Based Course Book For Learning Material Development Course
}

\author{
Desak Putu Parmiti \\ Jurusan Teknologi Pendidikan Fakultas Ilmu Pendidikan \\ Universitas Pendidikan Ganesha \\ Singaraja, Indonesia \\ dp-parmiti@undiksha.ac.id
}

\begin{abstract}
This study was aimed at producing a course book for material development course at Educational Technology Department of the Faculty of Educational Science, Universitas Pendidikan Ganesha through a lesson study as an effort to improve quality of instruction. This study was a development research. The course development used Hannafin and Peck material development model that consists of need analysis, design, development and implementation, evaluation and revision. The data were analyzed using descriptive analysis technique and inferential statistical analysis (t-test). The results showed that (1) the course book was developed following the stages of analysis, design, development and implementation with evaluation and revision in each stage; (2) the course book got a good score from experts, and the students; and (3) the course book was evaluated through lesson study which showed that there is a significant difference in the students' achievement between before and after using the course book.
\end{abstract}

Keywords—course book, lesson study, learning achievement

\section{INTRODUCTION}

Competency is something that has always been the topic of discussion in various aspects of life. Especially in educational sector, it is always used as a criterion by educational practitioners in conducting educational practices. According to Act No 14 of 2005 concerning teachers and lecturers, competency is a set of knowledge, skills, and behaviors that ought to be possessed, experienced and comprehended fully as well as mastered by teachers and lecturers in conducting their professional duties [1]. Based on that definition, competency is a set of expertise and capabilities that a teacher or a lecturer ought to possess to be able to do his or her job well to produce a teaching and learning process in accordance with the desired goal. This indicates that before educating the students to become competent, the educator ought to be competent. Therefore, a teacher or a lecturer as an educator plays an important role in education and needs to be developed to become a professional educator. With a professional attitude it is hoped that he or she can offer a quality education in an effort to develop reliable human resources in academic, socio-personal and vocational aspects.

One of the problems or topics that have been interesting to discuss in education recently is teaching effectiveness. A less than effective teaching tends to focus on how a teacher teaches rather than how students learn. This paradigm triggers an instructional implementation that tends to be conventional, that is, through oral communication technique. This understanding is of course in opposition to the understanding of constructionists [2]. These scholars state that teaching means designing external events to support the development of learning process on the part of the students which is internal in nature. This conception has two major points: (1) teaching is something that is designed by the educator and (2) the objective of teaching is to improve or to support the learning process on the part of the students. In addition to the educator factor, the less effectiveness of teaching is also due to learning resources, that is, a set of materials designed systematically to reach a competency. Course books are different from textbooks. Textbooks are not designed based on competencies of a course but are more oriented towards a general objective. This phenomenon also occurs in the teaching of instructional materials development in Educational Technology Department of Educational Science Faculty of Ganesha University of Education. In which textbooks are still used as the students' handbooks. The result of study shows that teaching that only uses textbooks can cause a low learning achievement. Based on scholars' opinions and the result of that study there is a significant effect of instructional design on quality of teaching.

As one of the alternative solutions in overcoming the teaching practice problem of less effective teaching is through an implementation of lesson study. Lesson study is an educational professional development model through investigating teaching collaboratively and sustainably based on collegial principles and mutual learning to develop a learning community [3]. Lesson study is conducted systematically in which the educator's performance is systematically developed collaboratively by preparing lesson plans and teaching materials, doing observations, reflections and revisions of lesson plans cyclically and continually. The alternative solution proposed to solve the problem of non-existing course books is by developing them.

The importance of developing course books lies in the function of the writing of them. In terms of their function, course books are very crucial since the writing of one gives a great contribution to success in learning. According to 
Departemen Pendidikan Nasional, based on people who use them, there are two functions of the writing of course books: for the educators and for the students [4]. For the educators the course books can (1) save the time in teaching, (2) change the role of educator as a teacher into a facilitator, (3) improve learning process to become a more effective and more interactive one, (4) as a guide for the educator that will orient all the activities in the learning process, and (5) as an instrument of evaluating the achievement or mastery of learning. For the students the teaching materials can (1) facilitate self-learning, (2) make learning more flexible, (3) learning can be fit into the speed of each student, (4) the students learn according to the sequence that they choose by themselves, (5) it helps to develop the students' potentials to become autonomous learners, and (6) as a guide for the students who will direct all their activities in the learning process. The function of the teaching materials based on the teaching strategy used is that they can be used in classical, individual and group learning.

The development of course books follows the instructional product developmental model. What makes it different from other developments is in the designing, developmental, and implementation phases of educational books in the classroom which are done through lesson study activities. Some considerations are: general competencies in the educational books and refer teaching materials can be broken into more complete, logical and systematical specific competencies since they are formulated by some lecturers who teach the same course that they can complement with each other and collaborate; (2) the design of the teaching focuses on accommodating optimal students' competency development; (3) the implementation of the course books is more optimal since the result of the analysis by the lesson study team becomes the guide in improving the quality of teaching process in the next meeting; and (4) improvement of the quality of teaching process and learning achievement as the effect of improvement of the weaknesses of the teaching process. These considerations are made with the reference to the major goal of lesson study according to Bill Cerbin \& get Bryan Kopp, that are (1) to gain some better experience about how students learn and teachers teach; (2) to get certain results that are useful for the other educators in how to teach; (3) to improve teaching systematically through collaborative inquiry (4) to develop a pedagogical knowledge, in which an educator can learn from other educators [5]. Catherine Lewis states that one of the essential characteristics of lesson study is that it focuses on materials that are regarded important but are the weak points in the teaching of the students and very difficult to learn. The course books that are developed through lesson study can be expected to help the students in facilitating them in understanding the materials that they regard difficult [6].

In addition to the considerations above, the results of research done by Winarsih and Mulyani showed that the development of learning materials through lesson study has been able to improve the learning process and achievement of the students. Based on some advantages and of lesson study, the importance of course books as one kind of learning materials, and results of research, then the researcher was interested in doing a study entitled [7].

By referring to the above discussion, the aims of this study were (1) to describe the procedures in course book development, (2) to describe the results of validation of the course book developed by experts and students, and (3) to explain the effectiveness of the course book developed in improving the students' learning achievement.

\section{METHODS}

This study was a development study. Development study is a study that is oriented towards the development and validation of products used in education [8]. This study used pre-experimental one group pretest posttest design. The design can be seen in Figure I.

\begin{tabular}{|c|c|c|}
\hline Pretest & $\begin{array}{c}\text { Independent } \\
\text { Variable }\end{array}$ & Posttest \\
\hline $\mathrm{O} 1$ & $\mathrm{X}$ & $\mathrm{O} 2$ \\
\hline
\end{tabular}

Fig. 1. Pre-experimental Design

By using Hannafin \& Peck's model (1987) which consists of three major processes, namely: need assessment, design and development and implementation, the course book was developed. The evaluation and revision were made in three phases.

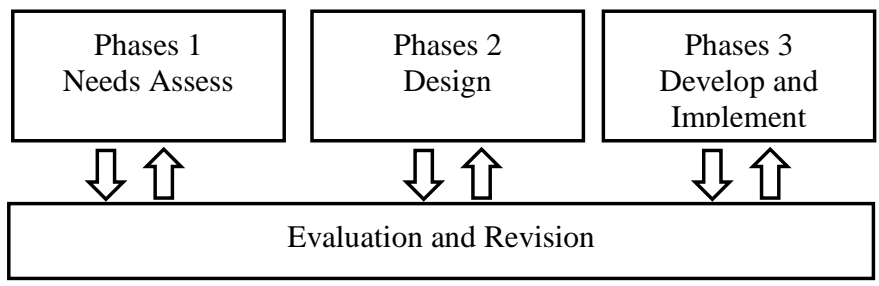

Fig. 2. Phases in Hannafin \& Peck's Model

In the need assessment stage some activities were done. They were (1) analysis of instructional problems, (2) analysis of competencies required from the students, (3) analysis of the students' characteristics in terms of learning capacity, knowledge, skills, attitudes and other relevant aspects, (4) analysis of materials that suit the requirements of the competencies and (5) analysis of learning resources. In the design stage the action was focused on three activities: (1) materials selection that meets the characteristics of the students and the requirements of the competencies, (2) instructional strategy selection and (3) design of the format and method of assessment used. In the development and implementation stage the course book prototype as the product of development was produced. In the development of the course book, the researcher sought all resources and references, drew pictures, charts and tables to support the presentation of the materials, typed the materials, determined the layout, wrote the instruments of evaluation, and other things related to the materials development. 
The product was a course book that had to be tried out in the real situation in the field to obtain the picture about the level of validity, effectiveness, and attractiveness. There were three activities done in the implementation stage. They were (1) planning, (plan), (2) implementation (do) and (3) reflection (see). The lesson study team planned the designing of materials, consisting of the writing of the syllabus, lesson plans, student worksheets, instruments of evaluation, and the course book. In the implementation (do) stage, the model lecturer implemented the materials and the course book. Before the teaching started, a pretest was given and then the teaching was carried out using the course book for four meetings. During the implementation of the course book through lesson study, a project based teaching was implemented. At the end of the fourth meeting a posttest was given to find out whether an improvement was made in the effectiveness of the teaching. The lesson study team played the role as observers. In the reflection (see) stage, the lesson study team met and then the model lecturer explained the constraints faced during the teaching process, and then the observers were invited to present the result of observation and analysis of the result which was then used to improve the teaching.

The evaluation and revision activities took place from the beginning to the end so that there were evaluation and revision activities in every stage. To evaluate the course book Dick, Carey and Carey formative evaluation model was used. The model covers three stages: individual evaluation ( 3 persons), small group evaluation (12 persons), and field evaluation (38 persons). The three stages of evaluation were started by expert reviews: content, media and design reviewers [5].

The data were collected using questionnaire, test and observation methods. The data collected were then analyzed using qualitative descriptive, quantitative descriptive analyses and inferential statistical analysis (t-test). The inferential statistics or the t-test was used to analyze the score difference between the pretest and the posttest of the course book implementation.

\section{RESUlT AND DiscusSiON}

The product of this research and development is a course book, which was developed in a Hannafin \& Peck's model (1987) that consists of three major processes: need assessment, design, and implementation and in each of the processes evaluation and revision are done. The picture of the product of the development can be seen in Figure 3.

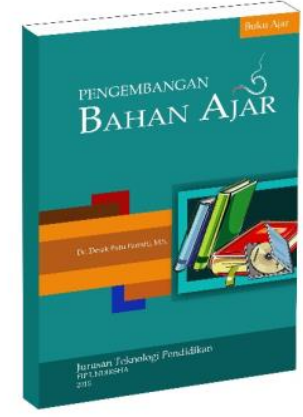

\section{Fig. 3 Product of the Development}

The development of the course book followed a series of validations by experts. The result of the content expert showed that the course book is good. This means that the course book contains facts, concepts, principles and procedures that are suitable for the students. The result of media expert's validation showed that the course book falls into a good category. This indicates that the pictures in the course book are suitable in explaining the concepts, principles, and procedures in the course book. The result of design validation showed that the course book meets the criteria for instructional design, instructional message design and the appropriateness in the use of the types of assessment.

After the course book went through the validation processes by the experts, it was evaluated by the students. The result of personal evaluation (by 3 students), small group evaluation (by 12 students) and field evaluation (38 students) showed that the course book has a good level of validity. This indicates that in terms of clarity, capability of motivating, attractiveness, and facility in understanding the materials, the course book is regarded as suitable to be used by the students. This is also supported by the opinion of a student who wrote a comment in the instrument that "the course book is good and easy to understand".

The course book that has gone through a series of expert evaluations and student evaluations and some improvements has been made. Then it was used in a class to find out the level of its effectiveness in improving the students' learning achievement. In using the course book lesson study approach was implemented. The result of paired samples ttest showed that the significance level obtained was 0.001 , less than the criterion level (0.05). This means there is a significant level between the students' learning achievement before and after learning Material Development through the course book. The mean score of the pretest was 71.42 and the mean score of the posttest was 85.15. The result of the ttest using SPSS is shown in Table 1 as follows.

TABLE I PAIRED SAMPLES TEST

\begin{tabular}{|c|c|c|c|c|c|c|c|c|c|}
\hline & & \multicolumn{5}{|c|}{ Paired differences } & \multirow[t]{3}{*}{$\mathrm{t}$} & \multirow[t]{3}{*}{ df } & \multirow{3}{*}{$\begin{array}{l}\text { Sig. (2- } \\
\text { tailed) }\end{array}$} \\
\hline & & \multirow[t]{2}{*}{ Mean } & \multirow[t]{2}{*}{$\begin{array}{c}\text { Std. } \\
\text { deviation }\end{array}$} & \multirow[t]{2}{*}{$\begin{array}{l}\text { Std. } \\
\text { Error } \\
\text { Mean }\end{array}$} & \multicolumn{2}{|c|}{$\begin{array}{l}\text { 95\% Confidence } \\
\text { Interval of the } \\
\text { Difference }\end{array}$} & & & \\
\hline & & & & & Lower & Upper & & & \\
\hline $\begin{array}{l}\text { Pair } \\
1 \\
\end{array}$ & $\begin{array}{l}\text { Pretest- } \\
\text { posttest }\end{array}$ & $\begin{array}{c}- \\
13.728 \\
\end{array}$ & 10.765 & 1.746 & $\begin{array}{c}- \\
17.266 \\
\end{array}$ & $\begin{array}{c}- \\
10.189\end{array}$ & $\begin{array}{c}- \\
7.861 \\
\end{array}$ & 37 & 0.001 \\
\hline
\end{tabular}


Based on the t-test result it is apparent that the course book can effectively improve the students' learning achievement. This result is parallel to the result of Lee and Osman's study that shows that a course book is effective in improving the students' learning achievement [9].

There are some factors that caused the difference in mean score of learning achievement between before and after using the course book. First, the course book was developed based on learning theories, instructional theories, and instructional message design theory. Thus, the course book is oriented to the learning process that takes place because of the synergy of short term memory and long term memory being activated through the creation of external factor or learning environment [10]. The course book as one of the components of the learning environment contains texts, pictures, illustrations, cases, and a number of authentic tasks that motivated the students to read, relate their prior knowledge and new knowledge, discuss, and implement theories in a real situation. These practice activities are parallel to what is stated by Silberman that "what I listen, see, discuss and do give me knowledge and skills" [11].

The course book was developed based on learning theories. The presentation of the materials in the course book was based on learning events or learning activities as stated by Gagne, Briggs and Wagner [2]. The aim of using the learning events was to avoid a direct instruction presentation. The presentation of materials through texts and pictures was not merely transfer of knowledge which made the students passive receivers of the message. A course book was designed to support learning, which was constructivist and aimed at helping the students explore topics and generalize knowledge. The principles of learning activities in writing a course book were: (1) it attracts the students' attention, (2) it delivers the goal of instruction, (3) it activates the students' prior knowledge, (4) it presents the contents of instruction, (5) it gives guidelines to learn, (6) it gives opportunities to perform, (7) it presents feedbacks, (8) it evaluates, and (9) it provides tasks to encourage transfer and retention of knowledge.

Learning message theory had a great impact on the implementation of the principles of motivation, memory, perception, and concept learning. The principle of motivation was implemented through the attractiveness of the book cover. The book cover design reflected the contents of the book and gave positive impression to the students about the contents. Not only the book cover, the principle of motivation was also applied to the giving of examples related to abstract material, clarity and relevance of pictures, and presenting interesting, challenging, and suspenseful topics. The principle of memory was implemented through presenting concrete messages, repetition of difficult materials, concept, principle, and procedure implementation practices. The principle of perception was implemented through varying word or phrase shapes such as bolding, underlining, using different fonts, changing letter color, and giving description to pictures to help perception. The implementation of the principle of concept learning was done through presenting easier concepts first before difficult ones, using examples and non-examples, using varied examples and using the characteristics of examples and contrary non-examples.

Second, the implementation of a course book in the class follows lesson study approach and this also influenced the effectiveness of the course book in improving the students' learning achievement. In the do stage, the model lecturer and the lesson study team made course program units, handout, and student worksheet. In course program units it was set that project based instruction will be used as the instructional model in implementing the course book, the use of test assessment, and project assessment. In the do stage, the course book was used in the project based instructional model and was designed for four meetings. It turned out that the use of the project- based instructional model had a positive impact on the students' process and result.

Through this instructional model, the students were required to produce authentic products. This requirement made the students feel challenged to do the task since the products that they were going to produce were not only useful for them but also for other people, especially for schools. The choice of project-based instructional model was supported by the result of the study done by Memisoglu that shows that a project-based instruction can help the students to access information, improve understanding, and ability to practice compared to the traditional instruction. Thus, the choice of project-based instructional model in implementing a course book is relevant and can improve the students' learning achievement [12].

During the implementation of the course book, the interaction in learning went in multi-directions. The interactions that occurred were between students and their fellow students, students and the lecturer, students and the course book and even between students and experts. The occurrence of these interactions were caused by the reflection at the end of every instruction in which the lesson study team gathered to reflect (see) to improve learning. The model lecturer as the instructional leader could improve herself and improve the instruction for the next meeting. The presence of authentic tasks also encouraged the students to make interactions since the tasks had to be done cooperatively and collaboratively with peers and related parties such as schools.

Within four meetings there was an improvement in the students' participation. The students started to be brave to ask questions, answer questions, do dialogues, share roles, and do the tasks that were assigned which they were responsible for.

Psychologically, effectiveness could be influenced by the student's interest in the instruction. An inspiring, interactive, joyful, challenging and motivating instruction is the instruction expected by students. Developing such kind of instruction was done through planning, observing the implementation, and reflecting, all of which were done by the lesson study team to improve the weaknesses so that the next instruction was better than the previous one. The lesson study process was done at the course book implementation 
stage and could develop an interesting instruction for the students that they did not feel disturbed with the presence of the observer.

The lesson study process gave a positive effect on the model lecturer. It turned out that the reflection in every meeting done the lesson study team could improve the model lecturer's skill. The lecturer became more open to inputs given by the observer and could cooperate better with colleagues in facilitating the students in building their knowledge. Indirectly, the activity has contributed to the optimization of the use of the course book in instruction. Thus, the lesson study activity becomes an approach to encourage a lecturer to become more professional and this has an impact on educational quality in a wider scope.

\section{CONCLUSION}

The course book was developed using Hannafin and Peck's model (1987) which was using lesson study approach. The validity of the course book in terms of content, media and design fell into category Good. The same is true for the result of evaluation by the students at the time of individual evaluation, small group evaluation, and field evaluation that showed that the quality of the course book falls into category good. The implementation of the course book in instruction using lesson study approach turned out to be effective in improving the students' learning achievement.

The findings of this study are that (1) the presentation of instructional messages using texts and pictures facilitated and speeded up the student's interpretation, retention, and transfer of knowledge by the students rather than when only texts were used; (2) The instructional design in the course book played a role in creating constructivist learning material so that it did not put the students in a message passive receiver role and (3) the implementation of the course book using lesson study approach had a positive effect on the students and the lecturer because the reflection activity became the reference by the model lecturer in improving the instruction so that the students were facilitated well in developing attitude, knowledge and skills.

\section{REFERENCES}

[1] R. Indonesia, Guru dan Dosen. Indonesia, 2005.

[2] R. M. Gagné, Principles of Instructional Design. Thomson/Wadsworth, 2005.

[3] Rusman, "Model-Model Pembelajaran: Mengembangkan Profesionalisme Guru." Rajawali Pers PT RajaGrafindo Persada. Jakarta, 2010.

[4] Direktorat Pembinaan SMA, Panduan Bahan uji Berbasis TIK. 2010.

[5] W. Dick, L. Carey, and J. O. Carey, The Systematic Design of Instruction. .
[6] C. Lewis, "Does Lesson Study Have a Future in the United States?," JSSE - J. Soc. Sci. Educ., vol. 3, no. 1, Jan. 2004.

[7] A. Winarsih and S. Mulyani, "Peningkatan Profesionalisme Guru IPA Melalui Lesson Study dalam Pengembangan Model Pembelajaran PBI," JPII, vol. 1, no. 1, pp. 43-50, 2012.

[8] M. D. Gall, J. P. Gall, and W. R. Borg, Educational Research : an Introduction. Pearson/Allyn \& Bacon, 2007.

[9] T. Tien Lee and K. Osman, "Interactive Multimedia Module with Pedagogical Agents: Formative Evaluation,” Int. Educ. Stud., vol. 5, no. 6, pp. 50-64, Sep. 2012.

[10] A. S. Dewi Salma Prawiradilaga, Santi Maudiarti, Prinsip Disain Pembelajaran (Instructional Design Principles). Jakarta: Prenada Media Group, 2008.

[11] Mel Silberman, Pembelajaran Aktif: 101 Strategi untuk Belajar Secara Aktif. Jakarta: PT. Indeks, 2013.

[12] H. Memişoğlu, "The Effect of Project Based Learning Approach in Social Sciences Class on the Student Success and Memorability*," Int. J. Humanit. Soc. Sci., vol. 1, no. 21, 2011. 